Arq. Bras. Med. Vet. Zootec., v.67, n.6, p.1539-1546, 2015

\title{
Subarachnoid injection of ifenprodil and ketamine association improves the anti-hyperalgesic action of ketamine in dogs
}

\author{
[Injeção subaracnoidea da associação ifenprodil e cetamina melhora a \\ ação anti-hiperalgésica da cetamina em cães] \\ E.S. Rondon ${ }^{1}$, C.A.A. Valadão ${ }^{2}$, C.A. Parada ${ }^{3}$ \\ ${ }^{1}$ Faculdade de Medicina Veterinária e Zootecnia - Universidade Federal de Mato Grosso do Sul \\ - FAMEZ-UFMS - Campo Grande, MS \\ ${ }^{2}$ Faculdade de Ciências Agrárias e Veterinárias - Universidade Estadual Paulista Júlio de \\ Mesquita Filho -Unesp- Jaboticabal, SP \\ ${ }^{3}$ Instituto de Biologia - Universidade Estadual de Campinas -UNICAMP - Campinas, SP
}

\begin{abstract}
To test clinically whether a small dose of ifenprodil can enhance the anti-hyperalgesic effect of ketamine in dogs, a prospective randomized cross-over study was done with eight mongrel dogs (weighing $16.9 \pm$ $3.7 \mathrm{~kg})$. Animals received two distinct treatments: ketamine $(0.3 \mathrm{mg} \mathrm{kg}-1 ; \mathrm{KT})$ and an ifenprodil plus ketamine combination $\left(0.03 \mathrm{mg} \mathrm{kg}^{-1}\right.$ and $0.3 \mathrm{mg} \mathrm{kg}^{-1}$, respectively; IKT). Dogs were anesthetized with propofol (5 $\mathrm{mg} \mathrm{kg}^{-1}$ intravenously) and a subarachnoid needle was placed between the $5^{\text {th }}$ and $6^{\text {th }}$ lumbar vertebrae. Five minutes after subarachnoid injection of KT or IKT, an incision including cutaneous and subcutaneous tissues was made on the common pad of one hind limb and was immediately closed with a simple interrupted suture pattern. The dogs were treated again 20 days later, using the contralateral pad and the opposite treatment. Sedation score (SS), lameness score (LS), heart rate (HR), respiratory rate $\left(f_{R}\right)$, and mechanical nociceptive threshold using von Frey filaments, were evaluated before anesthesia and at $1,1.5,2,3,4,8,12$, and 24 hours after subarachnoid injection. There were no differences in SS, LS, HR or $f_{R}$ between treatments. The intensity of hyperalgesia was higher in KT than in IKT for 24 hours. The anti-hyperalgesic effect of IKT remained without statistical significant difference between 1 and $24 \mathrm{~h}$. Prior subarachnoid administration of ifenprodil enhances the anti-hyperalgesic effect of subarachnoid ketamine in dogs. Ifenprodil can be co-administrated with ketamine to enhance its antihyperalgesic effect and to reduce acute post-incisional hyperalgesia without motor impairment and sedation.
\end{abstract}

Keywords: analgesia, inflammatory pain, NMDA, pain, subarachnoid

\section{RESUMO}

Com a finalidade de testar se uma dose baixa de ifenprodil pode melhorar a ação anti-hiperalgésica da cetamina em cães, um estudo randomizado prospectivo no formato cross-over foi realizado em oito cães sem raça definida (pesando 16,9 $\pm 3.7 \mathrm{~kg}$ ). Os animais receberam dois tratamentos distintos: cetamina $(0,3 m g ~ k g-1 ; K T)$ e a associação de ifenprodil com cetamina $(0,03 \mathrm{mg} \mathrm{kg}-1$ e $0,3 \mathrm{mg} \mathrm{kg}-1$, respectivamente; IKT). Os cães foram anestesiados com propofol $\left(5 \mathrm{mg} \mathrm{kg}{ }^{-1}\right.$, via intravenosa), e uma agulha subaracnoidea foi introduzida entre a quinta e sexta vértebras lombares. Após cinco minutos da injeção subaracnoidea de KT ou IKT, uma incisão abrangendo os tecidos cutâneo e subcutâneo foi realizada no coxim plantar comum de um dos membros pélvicos e imediatamente fechada com um padrão de sutura simples e interrompido. Os cães foram novamente tratados após 20 dias, usando-se $o$ coxim plantar contralateral e o outro tratamento. Os escores de sedação (SS) e claudicação (LS); as frequências cardíacas (HR) e respiratória $\left(f_{R}\right)$ e o limiar nociceptivo ao estímulo mecânico, utilizando os filamentos de von Frey, foram avaliados antes da anestesia e uma, uma e meia; duas; três; quatro; oito;

Recebido em 10 de outubro de 2014

Aceito em 14 de julho de 2015

E-mail: itacron@gmail.com 
12 e 24 horas após a injeção subaracnoidea. Não foram observadas diferenças significativas em SS, LS, HR ou na $f_{R}$ entre os tratamentos. A intensidade da hiperalgesia foi maior em KT que em IKT nas 24 horas. $O$ efeito anti-hiperalgésico de IKT se manteve sem diferença significativa entre os tempos uma hora e 24 horas. A administração prévia de ifenprodil aumentou a ação anti-hiperalgésica da cetamina subaracnoidea em cães. $O$ ifenprodil pode ser coadministrado com cetamina para aumentar seu efeito anti-hiperalgésico e reduzir a hiperlagesia aguda pós-incisional, sem alterações motoras e sedação.

Palavras-chave: analgesia, dor inflamatória, NMDA, dor, subaracnoide

\section{INTRODUCTION}

The NMDA (N-methyl-D-aspartate) receptor controls the cellular permeability to monovalent cations and calcium through a coupled ion channel and is involved with the development of acute neuropathic and inflammatory pain (Ridel and Neeck, 2001).

A functional NMDA receptor is composed of one NR1 subunit and one or more NR2 subunits (A, B, C or D). An NR3 subunit (A or B) can also be found. Activation of the NMDA receptor depends on the removal of a $\mathrm{Mg}^{+2}$ block and, simultaneously, on the interaction of glutamate and glycine at their respective sites of action, NR1 and NR2 (Errenger et al., 2004). It has been reported that opening of the ion channels coupled to NR2A and NR2B subunits results in higher levels of conductance than NR2C and NR2D subunits (Candy et al., 2001). In addition, painful states cause an increase of polyamines in central nervous system (CNS), enhancing the activity of NR2B subunit and its role in nociceptive transmission (Chizh et al., 2001).

Ketamine is a noncompetitive NMDA receptor antagonist widely used to control moderate to severe pain. Its analgesic effect has been demonstrated in rats (Oatway et al., 2003) and in humans (Kvarnströ et al., 2003). Ketamine blocks the NR1 subunit (Liu et al., 2001) of NMDA receptor at the internal portion of the ion channel coupled to the receptor, more specifically at its phencyclidine site. In addition, ketamine appears to block NMDA receptor by an allosteric mechanism, at a site within the lipidic portion of the cellular membrane (Orser et al., 1997).

Ifenprodil has been successfully used as an analgesic in several models of rodentneuropathic and inflammatory pain (Xu and Yang, 2006). In dogs, ifenprodil cardiovascular proprieties were tested (Mizusawa and Sakakibara, 1975) but until now it is not had been tested in pain models.

Ifenprodil is not structurally related to the conventional NMDA receptor antagonists, and it selectively inhibits the NR2B subunit of NMDA receptor. It appears to competitively interact with the polyamine site, increasing the NR2B subunit sensitivity to blockade of the ion channel by protons, and forcing the agonist-bound NMDA receptor to a conformation with low probability of opening (Mott et al., 1998). It has also been reported that ifenprodil can allosterically interact in a non-competitive manner with the $\mathrm{Mg}^{+2}$ binding site of NR1 subunit (Kew and Kemp, 1998).

In rats, the pre-emptive intrathecal administration of very small doses of ifenprodil, immediately prior to subarachnoid administration of ketamine, significantly enhances the anti-hyperalgesic effect, compared to intrathecal administration of ketamine alone. This combination was shown to be useful to control inflammatory pain with less undesirable systemic effects than ketamine alone (Rondon et al., 2010).

The aim of this study was to investigate if subarachnoid injection of ifenprodil immediately prior to subarachnoid injection of ketamine enhances the anti-hyperalgesic effect of ketamine in dogs subjected to an incision in cutaneous and subcutaneous tissues. We hypothesized that nociceptive mechanical thresholds would be higher when ifenprodil is administered before ketamine subarachnoid injection.

\section{MATERIALS AND METHODS}

All animal experimental procedures and protocols were approved by an Institutional Committee on Animal Research (CEBEA, FCAV/Unesp-Jaboticabal, Processo $\mathrm{n}^{\circ}$ 004990-08). 
Eight healthy mongrel dogs (3-5 years, mean \pm SD weight $16.9 \pm 3.7 \mathrm{~kg}$ ), including three females out of gestational, proestrus or estrus periods, were used. Dogs were deemed healthy based on physical examination and laboratory tests (complete blood count, serum aspartate aminotransferase, serum alanine aminotransferase and blood urea nitrogen). The sample size was calculated (Eng, 2003) to minimize the number of animals used. All efforts were made to minimize their discomfort.

Dogs received two distinct treatments: ketamine $(0.3 \mathrm{mg} \mathrm{kg}-1 ; \mathrm{KT})$ or an ifenprodil and ketamine combination $(0.03 \mathrm{mg} \mathrm{kg}-1$ and $0.3 \mathrm{mg} \mathrm{kg-1}$, respectively; IKT). After clipping and aseptic preparation of the lumbosacral region, dogs were anesthetized with propofol (Propofol, Cristália Produtos Químicos e Farmacêuticos Ltda., Brazil) (5mg kg-1), administered through an indwelling IV catheter, and anesthesia was maintained with additional doses of this anesthetic as necessary. No endotracheal tube was placed and dogs were maintained without supplemental oxygen. Dogs were positioned in right lateral recumbency with the hind limbs directed cranially. A 22-gauge x $6.35 \mathrm{~cm}$ spinal needle (Spinal; Becton Dickinson Ind. Cirúrgicas Ltda., Brazil) was placed into the subarachnoid space between 5 th and 6th lumbar vertebrae and the correct needle positioning was confirmed by observation of cerebrospinal fluid draining. Ten percent Ketamine (Francotar, Eurofarma Laboratórios Ltda., Brazil) or $0.1 \%$ ifenprodil (Ifenprodil Tartrate Salt, Sigma-Aldrich, USA) followed by a $0.5 \mathrm{~mL}$ flush of saline solution and
$10 \%$ ketamine were administered in KT and IKT treatments, respectively. Doses were obtained from previous data in dose-response curves in rats (Rondon et al., 2010) and extrapolated (linear extrapolation by weight) to dogs. The final volume was adjusted to $0.15 \mathrm{~mL} \mathrm{kg-1}$ with isotonic saline solution (Cloreto de Sódio 0.9\%, Cristália Produtos Químicos e Farmacêuticos Ltda., Brazil). After injection of drugs, the needle was removed and dogs were rotated to sternal recumbency. Five minutes after subarachnoid injection, a $2 \mathrm{~cm}$ longitudinal incision was made including the cutaneous and subcutaneous tissues of the common pad of a hind limb (randomly selected). The incision was immediately closed with nylon (Nylon Monofilamentar 2-0, Cirumédica S.A., Brazil) suture, using a simple interrupted pattern. Dogs were maintained in sternal recumbency until they were able to stand and walk. After a 20-day washout period, the procedures were repeated on all dogs as described above, using the opposite treatment and the contralateral limb, totaling eight observations per treatment.

Sedation score (SS; Table 1), lameness score (LS; Table 2) (Duque et al., 2004), heart rate $(\mathrm{HR})$, respiratory rate $\left(\mathrm{f}_{\mathrm{R}}\right)$, and mechanical nociceptive threshold (MNT) were evaluated before anesthesia and 1, 1.5, 2, 3, 4, 8, 12 and 24 hours after subarachnoid injection. Heart rate and fR were determined by thoracic auscultation with stethoscope. All the observations and measures were made in a non-blinded way by the same experimenter.

Table 1. Sedation scoring system

\begin{tabular}{lc}
\hline \multicolumn{1}{c}{ Sedation Score } & Score \\
\hline Behavior & 0 \\
\hline Alert and walking normally & 1 \\
Somnolent, standing with head down and eyes semiclosed & 2 \\
Somnolent, laterally or sternally recumbent, responds to calling & 3 \\
Somnolent, laterally or sternally recumbent, does not respond to calling & \\
\hline
\end{tabular}

Table 2. Lameness scoring system

\begin{tabular}{lcc}
\hline \multicolumn{1}{c}{ Lameness Score } & Score \\
\hline Position & & 0 \\
\hline Complete weight bearing & 1 \\
Partial weight bearing (standing and walking) & 2 \\
Partial weight bearing (standing only) & 3 \\
No weight bearing & \\
\hline
\end{tabular}


Mechanical nociceptive threshold (MNT) was assessed with von Frey filaments (Touch-Test Sensory Evaluator, North Coast Medical Inc, USA) in ascending order. Each filament was applied at 3-second intervals to four different points (cardinal points) located $3 \mathrm{~mm}$ away from the incision line. Measurements started by pressing the thinnest filament for 1 second until the nylon bents. The test was then repeated with the next filament until a response (withdrawal movement of limb) was obtained at 3 of the 4 points evaluated. The test was then interrupted and peri-incisional MNT was considered to be the force exerted by the previous thickest filament that did not elicit a response. If no response was obtained with the last filament (446.683g), the evaluation ceased and MNT was considered to be $447 \mathrm{~g}$. The magnitude of hyperalgesia was reported as $\Delta \mathrm{MNT}(\mathrm{g})$, which was calculated by subtracting the baseline MNT value (e.g., before spinal injection) from that measured at each time point after incision.
Changes in $\triangle \mathrm{MNT}$ over time, expressed as absolute values; heart rate and respiratory rate data were statistically analyzed using Two-way Repeated Measures ANOVA and Bonferroni post hoc test. Statistical significance was set at $\mathrm{P}<0.05$ (Graph Pad Software, San Diego, CA, USA). Data are reported as mean \pm SD.

\section{RESULTS}

Total anesthesia time was 30 minutes. No signs of CNS excitement were observed in any dog at any time point.

Sedation and lameness scores were 0 for the entire duration of the study. Baseline HR values were $101 \pm 14$ and $97 \pm 32$ beats per minute in KT and IKT, respectively. No significant change in HR over time was seen in either treatment, and no difference between treatments was detected (Table 3).

Table 3. Heart rate (mean \pm SD) before (baseline) and after subarachnoid administration of ketamine (KT) or ifenprodil plus ketamine (IKT) in eight dogs subjected to surgical incision

\begin{tabular}{|c|c|c|c|c|c|c|c|c|c|c|}
\hline & & \multicolumn{9}{|c|}{ Heart Rate } \\
\hline $\begin{array}{c}\text { Treatme } \\
\text { nt }\end{array}$ & Time (h) & $\begin{array}{c}\text { Baselin } \\
\mathrm{e}\end{array}$ & 1 & 1.5 & 2 & 3 & 4 & 6 & 12 & 24 \\
\hline KT & Mean $\pm S$ & & & $95 \pm 1$ & $94 \pm 1$ & $100 \pm 1$ & $97 \pm 1$ & & $102 \pm 1$ & \\
\hline$(n=8)$ & $\mathrm{D}$ & $101 \pm 14$ & $99 \pm 13$ & 6 & 5 & 9 & 5 & $93 \pm 14$ & 4 & $98 \pm 18$ \\
\hline IKT & Mean $\pm \mathrm{S}$ & & $105 \pm 1$ & $96 \pm 1$ & $87 \pm 1$ & $107 \pm 1$ & $96 \pm 1$ & $100 \pm 1$ & & $108 \pm 1$ \\
\hline$(n=8)$ & D & $97 \pm 23$ & 3 & 6 & 2 & 2 & 6 & 5 & $89 \pm 8$ & 2 \\
\hline
\end{tabular}

$\mathrm{SD}=$ standard deviation

Baseline $f_{R}$ was $21 \pm 3$ and $27 \pm 8$ breaths per minute in the KT and IKT, respectively. No significant change in $f_{R}$ over time was seen in either treatment, and no difference between treatments was detected (Table 4).

Table 4. Respiratory rate (mean \pm SD) before (baseline) and after subarachnoid administration of ketamine (KT) or ifenprodil plus ketamine (IKT) in eight dogs subjected to surgical incision

\begin{tabular}{|c|c|c|c|c|c|c|c|c|c|c|}
\hline & & \multicolumn{9}{|c|}{ Respiratory Rate } \\
\hline Treatment & Time (h) & Baseline & 1 & 1.5 & 2 & 3 & 4 & 6 & 12 & 24 \\
\hline $\begin{array}{c}\mathrm{KT} \\
(\mathrm{n}=8)\end{array}$ & Mean \pm SD & $21 \pm 3$ & $22 \pm 6$ & $22 \pm 4$ & $23 \pm 5$ & $23 \pm 5$ & $18 \pm 3$ & $19 \pm 7$ & $21 \pm 3$ & $20 \pm 4$ \\
\hline $\begin{array}{c}\text { IKT } \\
(n=8)\end{array}$ & Mean \pm SD & $27 \pm 8$ & $18 \pm 5$ & $24 \pm 4$ & $19 \pm 4$ & $25 \pm 7$ & $24 \pm 5$ & $22 \pm 4$ & $20 \pm 4$ & $22 \pm 5$ \\
\hline
\end{tabular}

$\mathrm{SD}=$ standard deviation

Mechanical nociceptive thresholds before treatment (baseline) were $396 \pm 31 \mathrm{~g}$ and $309 \pm 51 \mathrm{~g}$ in $\mathrm{KT}$ and IKT, respectively. The $\triangle \mathrm{MNT}$ calculated after incision was significantly different between treatments at all time-points (Figure 1). The $\triangle \mathrm{MNT}$ did not change over time in $\mathrm{KT}$ and $\operatorname{IKT}(\mathrm{P}=0.04)$. 


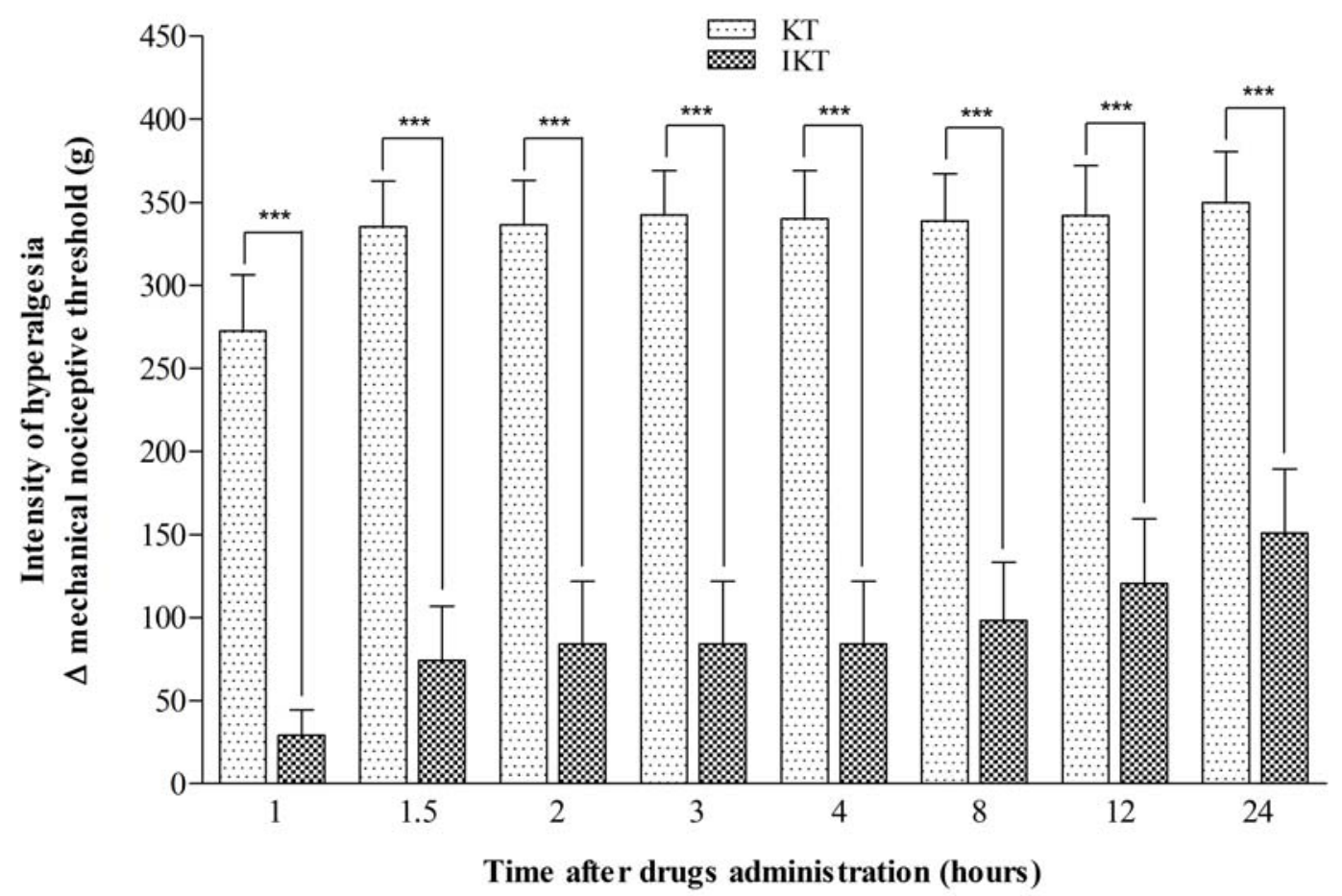

Figure 1. Time course of anti-hyperalgesic effect induced by combination of ifenprodil $(0.03 \mathrm{mg} \mathrm{kg}-1)$ and ketamine $(0.3 \mathrm{mg} \mathrm{kg}-1$; IKT) when compared with ketamine administered alone $(0.3 \mathrm{mg} \mathrm{kg}-1$; KT) in dogs subjected to surgical incision. Drugs were administrated (subarachnoid route) five minutes before the surgical incision. The MNT was measured by von Frey filaments and baseline values before surgery were 309g (IKT) and 396g (KT). The symbol*** means significantly different from $\mathrm{KT}(\mathrm{P}<0.001$, Two-way Repeated Measures ANOVA, Bonferroni post hoc test; eight dogs per treatment).

\section{DISCUSSION}

In this study, the subarachnoid injection of ketamine or ifenprodil plus ketamine did not produce signs of CNS excitement, sedation, or motor impairment in any dog. High doses of NMDA receptor antagonists have been reported to cause motor impairment (Boyce et al., 1999; Duque et al., 2004) however subanesthetic doses were administered in this study.

Propofol used for hypnosis in dogs has an anesthetic recovery time between 2 and 4 minutes, in part due to its rapid biotransformation (Morgan and Legge, 1989). Therefore, the first post-surgical evaluation was unlikely to be affected by the short propofol anesthesia. This is supported by the observation that SS did not change significantly from baseline to post-treatment measurements ( 1 to 24 hours).
The LS remained unchanged over time in both treatments indicating that animals felt comfortable in supporting the hind limb and also did not show motor abnormalities. Painful conditions have been associated with alterations in HR and fR (Grunau et al., 1998; Molony and Kent, 1997). In this study, these variables were not significantly different between treatments. This suggests that neither KT nor IKT had a direct effect on these variables, and that either both treatments were effective for reducing pain associated with cutaneous and subcutaneous incision or the pain produced by those incisions was insufficient to cause alterations in HR and $f_{R}$.

Previous data from our laboratory showed that intrathecal injection of low doses of ifenprodil, administered immediately prior to ketamine, enhances anti-hyperalgesic effect of the latter 
drug, compared to each drug administered alone, and prevented the hyperalgesia induced by intraplantar injection of $\mathrm{PGE}_{2}$ in rats (Rondon et al., 2010). This isobolographic study demonstrated that ifenprodil potentiates the antihyperalgesic effect of ketamine, in rats. Based on that, in this present study we clinically demonstrated that ifenprodil $(0.03 \mathrm{mg} \mathrm{kg}-1)$ was effective to significantly enhance the antihyperalgesic effect induced by the usual dose of ketamine (Duque et al., 2004).

Ketamine and ifenprodil act at NMDA receptor, which plays an important role in acute and chronic nociception (Oatway et al., 2003; Xu and Yang, 2006). It has been suggested that sensitization of peripheral nociceptor neurons results in continuous release of glutamate in the spinal cord and action of glutamate at NMDA receptors (Parada et al., 2003). The activation of NMDA receptors in spinal cord causes central sensitization (Eide, 2000) in addition to peripheral sensitization (Flossos, 2004). Moreover, a retrograde sensitization of primary sensory neurons can be mediated by release of glutamate and NMDA receptors in the spinal cord (Parada et al., 2003). Finally, inflammatory processes in peripheral tissues may facilitate the activation of NMDA receptors in the spinal cord (Stanfa et al., 1996).

Interestingly, the findings of this study demonstrated that modulation of NMDA receptors by ifenprodil can improve the antihyperalgesic action of a known effective dose of ketamine (Duque et al., 2004). The analgesic effects of ketamine appear to occur by the blockade of NMDA receptors when the coupled ion channel is closed (Orser et al., 1997).

It is also important to consider that NMDA NR1 subunit is widely expressed in the spinal cord gray matter; whereas, NMDA NR2B subunit is expressed mainly in laminas I and II, where most nociceptive primary afferents fibers terminate (Nagy et al., 2004). Therefore, NR2B selective antagonists, such as ifenprodil, at least when administered intrathecally, could be more selective in the control of nociception than ketamine (Boyce et al., 1999). The combination of ifenprodil and ketamine, could trigger NR1 blockade mediated by ketamine, selecting NMDA receptors containing NR2B. Therefore, this combination may greatly narrow these pharmacological actions on spinal cord nociceptive systems.

Although we observed that in the IKT, the antihyperalgesic effect after $1 \mathrm{~h}$ declined during the time, there was no significant statistic difference (Bonferroni post hoc test) until last measure (24 h). In the other hand, KT graphic showed a more linear pattern of effect. Differences in ketamine and ifenprodil pharmacokinetics may have contributed to this finding. However, it remains hypothetical since the pharmacokinetics of ketamine and ifenprodil following subarachnoid administration have not been reported in dogs.

A non-pharmaceutical grade of ifenprodil was used because there is not an injectable commercial form of this drug. However, it is described that ifenprodil has neuroprotective effects (Bath et al., 1996).

In the present study, it was demonstrated that ifenprodil (0.03 mg kg-1, subarachnoid) is effective in dogs for use prior to a subanesthesic dose of ketamine ( $0.3 \mathrm{mg} \mathrm{kg}^{-1}$, subarachnoid) to enhance its effect without motor impairment, clinical signs of neurological injury and sedation during, at least, 24 hours after a surgical incision. Similar observations were made in other species and also in dogs. Epidural or intrathecal injections of ketamine were not correlated with neurological injuries in ponies (Doherty et al., 1997) and dogs (Amarpal et al., 1999) but ifenprodil had not been tested yet.

\section{CONCLUSION}

Subarachnoid injection of ifenprodil immediately prior to subarachnoid injection of ketamine enhances the anti-hyperalgesic effect of ketamine in dogs subjected to an incision in cutaneous and subcutaneous tissues.

\section{ACKNOWLEDGEMENT}

This work was supported by grants of CAPES (Brasília, Brazil) and FAPESP (São Paulo, Brazil). 


\section{REFERENCES}

AMARPAL, K.; AITHAL, H.P.; SINGH, G.R. et al. Preemptive effects of epidural ketamine for analgesia in dogs. Indian Vet. J., v.76, p.300303, 1999.

BATH, C.P.; FARRELL, L.N.; GILMORE, J. et al. The effects of ifenprodil and eliprodil on voltage-dependent $\mathrm{Ca} 2+$ channels and in gerbil cerebral ischemia. Eur. J. Pharmacol., v.299, p.103-112, 1996.

BOYCE, S.; WYATT, A.; WEBB, J.K. et al. Selective NMDA NR2B antagonists induce antinociception without motor dysfunction: correlation with restricted localization of NR2B subunit in dorsal horn. Neuropharmacology, v.38, p.611-623, 1999.

CANDY, S.C.; BRICKEY, S.; FARRANT, M. NMDA receptor subunits: diversity, development and disease. Curr. Opin. Neurobiol., v.11, p.327-335, 2001.

CHIZH, B.A.; HEADLEY, P.M.; TZSCHENTKE, T.M. NMDA receptor antagonists as analgesics: focus on the NR2B subtype. Trends Pharmacol. Sci., v.22, p.636642, 2001.

DOHERTY, T.J.; GEISER, D.R.; ROHRBACH, B.W. The effect of high volume epidural morphine, ketamine, and butorphanol on halothane minimum alveolar concentration in ponies. Equine Vet. J., v.29, p.370-373, 1997.

DUQUE, J.C.M.; VALADÃO, C.A.A.; FARIAS, A. et al. Pre-emptive epidural ketamine or $\mathrm{S}(+)$-ketamine in post-incisional pain in dogs: a comparative study. Vet. Surg., v.33, p.1-7, 2004.

EIDE, P.K. Wind-up and the NMDA receptor complex from a clinical perspective. Eur. J. Pain, v.4, p.5-17, 2000.

ENG, J. Sample size estimation: how many individuals should be studied? Radiology, v.227, p.309-313, 2003.

ERRENGER, K.; CHEN, P.E.; WYLLIE, D.J.A. et al. Glutamate receptor gating. Crit. Rev. Neurobiol., v.16, p.187-224, 2004.

FLOSSOS, A. An introduction to the neurobiology of pain. Greek E-J. Perioper Med., v.2, p.2-10, 2004.
GRUNAU, R.E.; OBERLANDER, T.; HOLSTI, L. et al. Bedside application of the neonatal facial coding system in pain assessment of premature infants. Pain, v.76, p.277-286, 1998.

KEW, J.N.C.; KEMP, J.A. An allosteric interaction between the NMDA receptor polyamine and ifenprodil sites in rat cultured cortical neurones. J. Physiol., v.512, p.17-28, 1998.

KVARNSTRÖ, A.; KARLSTEN, M.R.; QUIDING, $\mathrm{H}$. et al. The effectiveness of intravenous ketamine and lidocaine on peripheral neuropathic pain. Acta Anaesthesiol. Scand., v.47, p.868-877, 2003

LIU, H.T.; HOLLMANN, M.W.; LIU, W.H. et al. Modulation of NMDA receptor function by ketamine and magnesium: part I. Anesth Analg., v.92, p.1173-1181, 2001.

MIZUSAWA, H.; SAKAKIBARA, E. [Effects of 2-(4-benzyl-piperidino)-1-(4-hydroxyphenyl)1-propanol (ifenprodil) on the cardiovascular system in vivo]. Folia Pharmacol. Jap., v.71, p.597-608, 1975.

MOLONY, V.; KENT, J.E. Assessment of acute pain in farm animals using behavioral and physiological measurements. J. Anim. Sci., v.75, p.266-272, 1997.

MORGAN, D.W.T.; LEGGE, K. Clinical evaluation of propofol as an intravenous anaesthetic agent in cats and dogs. Vet. Rec., v.124, p.31-33, 1989.

MOTT, D.D.; DOHERTY, J.J.; ZHANG, S. et al. Phenylethanolamines inhibit NMDA receptors by enhancing proton inhibition. Nat. Neurosci., v.1, p.659-667, 1998.

NAGY, G.G.; WATANABE, M.; FUKAYA, M. et al. Synaptic distribution of the NR1, NR2A and NR2B subunits of the N-methyl-D-aspartate receptor in the rat lumbar spinal cord revealed with an antigen-unmasking technique. Eur. J. Neurosci., v.20, p.3301-3312, 2004.

OATWAY, M.; REID, A.; SAWYNOK, J. Peripheral antihyperalgesic and analgesic actions of ketamine and amitriptyline in a model of mild thermal injury in the rat. Anesth. Analg., v.97, p.168-173, 2003. 
ORSER, B.A.; PENNEFATHER, P.S.; MACDONALD, J.F. Multiple mechanisms of ketamine blockade of N-methyl-D-aspartate receptors. Anesthesiology, v.86, p.903-917, 1997.

PARADA, C.A.; VIVANCOS, G.G.; TAMBELI, C.H. et al. Activation of presynaptic NMDA receptors coupled to $\mathrm{NaV1}$.8-resistant sodium channel $\mathrm{C}$ fibers causes retrograde mechanical nociceptor sensitization. Pharmacology, v.100, p.29232928, 2003.

RIDEL, W.; NEECK, G. Nociception, pain and antinociception: current concepts. Z. Rheumatol., v.60, p.404-415, 2001.
RONDON, E.S.; VIEIRA, A.S.; VALADÃO, C.A.A. et al. The improvement of the antihyperalgesic effect of ketamine and of its isomers by the administration of ifenprodil. Eur. J. Pharmacol., v.647, p.84-89, 2010.

STANFA, L.C.; MISRA, C.; DICKENSON, A.H. Amplification of spinal nociceptive transmission depends on the generation of nitric oxide in normal carrageenan rats. Brain Res., v.737, p.92-98, 1996.

XU, F.; YANG, J. Antiinflamatory pain effect of ifenprodil administrated subarachnoidly. Jiangsu Med. J., v.32, p.564-566, 2006. 